\title{
DESAIN DIDAKTIS SIFAT-SIFAT BANGUN DATAR SEGIEMPAT
}

\author{
Dwi Desmayanasari ${ }^{1}$, Desrina Hardianti ${ }^{2}$ \\ ${ }^{1,2}$ Universitas Muhammadiyah Lampung \\ dwidesmayana@gmail.com,
}

\begin{abstract}
Abstrak
Tujuan penelitian ini adalah menyusun desain didaktis sifat-sifat bangun datar segiempat. Penelitian ini merupakan penelitian kualitatif dimana Peneliti berperan sebagai alat pengumpul data utama dan didukung oleh instrumen lainnya seperti, lembar kerja siswa, pedoman wawancara, lembar observasi, foto, dan video rekaman saat pembelajaran. Subjek penelitian ini adalah siswa kelas VII SMP di Bandar Lampung. Pengumpulan data dilakukan dengan menggunakan teknik triangulasi. Analisis data dilakukan dengan menelaah seluruh data yang tersedia dari berbagai sumber, mulai dari sebelum, selama, dan setelah penelitian. Hasil penelitian ini yaitu: (1) Learning obstacle yang teridentifikasi pada penelitian desain didaktis sifat-sifat bangun datar segiempat yaitu epistemological obstacle, dan didactical obstacle, (2) Desain dikembangkan berdasarkan hasil analisis pendahuluan serta disesuaikan dengan learning trajectory untuk meminimalkan hambatan yang dialami siswa dalam memahami materi sifat-sifat bangun datar segiempat, (3) Desain didaktis empirik materi sifat-sifat bangun datar segiempat dikembangkan berdasarkan hasil analisis implementasi desain.
\end{abstract}

Kata Kunci: DDR, Sifat-sifat Bangun Datar Segiempat.

\begin{abstract}
The purpose of this research is to construct a didactic design of the properties of quadrilaterals. This research is qualitative research in which the researcher acts as the main data collection tool and supported by other instruments such as student worksheets, interview guides, observation sheets, photos, and video recordings during learning. The subjects of this research were students of class VII at a junior high school in Bandar Lampung. The data was collected using triangulation techniques. Data analysis was carried out by examining all data from various sources, starting before, during, and after the research. The results of this research are: (1) Learning obstacle identified in the didactic design research with the characteristics of quadrilateral, namely epistemological obstacle, and didactical obstacle, (2) The design was developed based on the results of preliminary analysis and adjusted to the learning trajectory to minimize obstacles that experienced by students in understanding the properties of quadrilateral, (3) Didactic empirical design of the quadrilateral properties is developed based on the results of the analysis design implementation.
\end{abstract}

Keywords: DDR, The Properties of Quadrilateral. 


\section{PENDAHULUAN}

Geometri merupakan suatu konsep yang penting dalam matematika. Konsep geometri tidak hanya dapat diterapkan dalam mempelajari konsep matematika itu sendiri, lebih dari itu, konsep geometri juga dapat diterapkan dalam kehidupan sehari-hari. Seseorang yang mempelajari geometri dapat menjadi pemecah masalah yang baik, dapat berkomunikasi secara matematis, dan dapat bernalar secara matematis [1]. Menurut Clements, konsep geometri dan penalaran spasial akan membentuk pondasi penting dalam pembelajaran matematika dan mengembangkan kemampuan matematika yang dimiliki siswa [2]. Terdapat beberapa alasan mengapa geometri diajarkan kepada siswa karena geometri merupakan cara untuk menginterpretasikan dan mendeskripsikan lingkungan secara fisik dan sebagai alat penting dalam pemecahan masalah. Geometry has a greater opportunity for students to understand than any other mathematical material [2]. Ide geometri merepresentasikan dan menyelesaikan permasalahan pada pokok bahasan matematika lainnya, seperti konsep luas dan konsep bilangan pecahan [3].

Uraian di atas menunjukkan bahwa konsep geometri penting diajarkan kepada siswa untuk mengembangkan pola pikir dalam menghadapi permasalahan, baik dalam matematika maupun dalam kehidupan sehari-hari. Namun fakta di lapangan menunjukkan hal sebaliknya. Masih banyak miskonsepsi yang berhubungan dengan geometri pada siswa kelas VII yang disebabkan karena siswa hanya menghafal rumus dari bangun geometri [4]. Sementara itu ditemukan fakta lain bahwa siswa hanya mengetahui konsep bangun datar dari bentuknya dan tidak dapat menyelesaikan permasalahan yang mengaitkan sifat-sifat antar bangun datar [5][6]. Hasil penelitian pendahuluan yang dilakukan menunjukkan bahwa masih terdapat beberapa hambatan dalam diri siswa dalam mempelajari geometri, khususnya pada materi sifat-sifat bangun datar. Hambatan yang dialami siswa terlihat dari jawaban-jawaban yang diberikan siswa pada saat tes learning obstacle.

Fakta di lapangan menunjukkan bahwa hanya terjadi proses transfer informasi dari guru ke siswa pada saat penyampaian materi yang menyebabkan kurangnya aktivitas berpikir siswa sehingga pembelajaran yang terjadi kurang bermakna. Siswa memahami konsep matematika secara terpisah-pisah, kurang terintegrasi dalam mengaitkan antara konsep yang satu dengan konsep yang lain. Sementara itu, dalam matematika, antara konsep yang satu dengan yang lain sangat erat kaitannya. Matematika dibangun berdasarkan konsep yang terstruktur, untuk memahami suatu konsep kita harus terlebih dahulu memahami konsep lain yang mendahului. Jadi, dalam prosesnya matematika dipelajari dari konsep yang mudah ke konsep yang lebih sulit. Hal tersebut berlaku juga dalam mempelajari konsep geometri. Contohnya untuk memahami sifat-sifat bangun datar, siswa harus memahami konsep garis dan sudut. Ini memperlihatkan keterkaitan antar konsep dalam matematika. Kurangnya pemahaman konsep prasyarat akan mempengaruhi pemahaman siswa dalam pembelajaran, yang akan memunculkan hambatan belajar (learning obstacle) bagi siswa. 
Hambatan belajar yang muncul bisa disebabkan oleh faktor siswa, faktor guru, atau pun saat proses pembelajaran. Hambatan belajar yang muncul dapat berupa hambatan ontogenik (ontological obstacle), hambatan epistemologi (epistimologis obstacle), maupun hambatan didaktis (didatical obstacle) [7]. Hambatan ontogenik merupakan hambatan yang dapat muncul akibat keterbatasan atau ketidaksiapan mental siswa dalam mengaitkan konsep dengan informasi yang ada [8]. Keterbatasan pengetahuan siswa dalam satu konteks tertentu juga dapat menjadi hambatan belajar atau disebut hambatan epistemologi, dimana siswa akan mengalami kesulitan untuk menggunakan pengetahuannya jika dihadapkan pada konteks yang berbeda. Ketidaksiapan guru dalam mempersiapkan materi dan aktivitas selama proses pembelajaran juga dapat menjadi hambatan belajar berupa hambatan didaktis, dimana proses pembelajaran yang terjadi kurang memperhatikan alur pikir dan kesiapan mental siswa [9].

Ontogenic obstacle merupakan hambatan yang berkaitan dengan tahapan mental siswa [8]. Didactical obstacle merupakan hambatan yang muncul akibat proses pembelajaran yang dilakukan oleh guru [9]. Duroux dalam suryadi [10], menyatakan bahwa epistemological obstacle merupakan pengetahuan seseorang yang hanya terbatas pada konteks tertentu, orang tersebut akan mengalami kesulitan dalam menggunakan pengetahuan yang dimilikinya bila dihadapkan pada konteks yang berbeda.

Dalam proses pembelajaran matematika aspek yang mendasar adalah siswa, guru, dan materi. Dari aspek tersebut terdapat hubungan antara siswa dan materi serta guru dan siswa yang menciptakan suatu hubungan didaktis dan pedagogis. Dimana menurut Kansanen [11] hubungan tersebut digambarkan sebagai segitiga didaktik yang menggambarkan hubungan pedagogis antara guru dengan siswa dan hubungan didaktis antara materi dengan siswa. Ilustrasi segitiga Kansanen seperti pada Gambar 1.

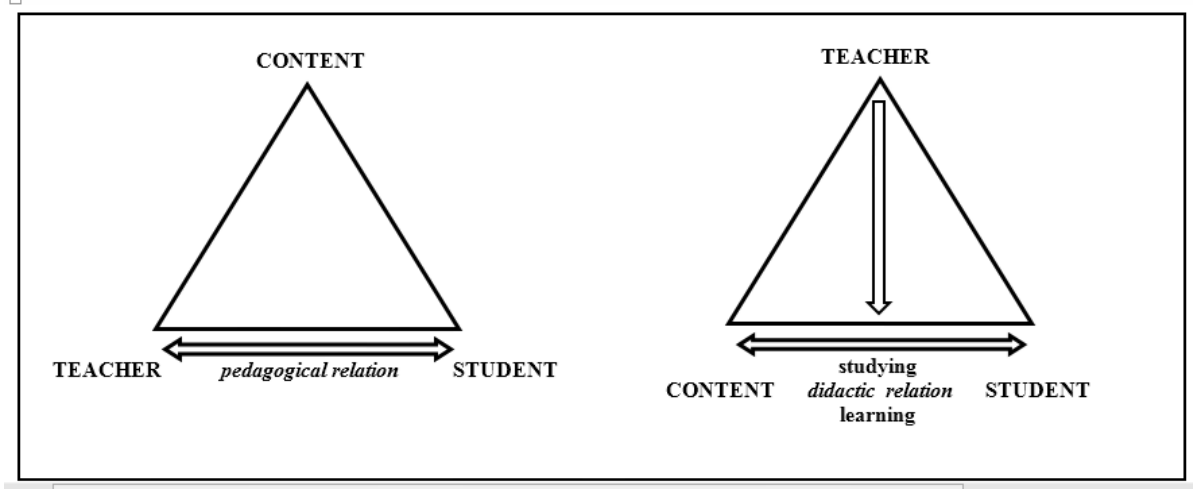

Sumber: Kansanen, 2003

Gambar 1. Segitiga didaktis Kansanen

Ilustrasi segitiga didaktis Kansanen tersebut belum memuat hubungan guru dan materi dalam konteks pembelajaran. Menurut Suryadi [12] hubungan didaktis dan 
pedagogis tidak bisa dipandang secara parsial dan merupakan satu kesatuan yang utuh dan hubungan tersebut dapat terjadi secara bersamaan.

Dalam merancang situasi didaktis, guru perlu memikirkan respon dari siswa dan antisipasi dalam menanggapi respon yang muncul sehingga akan tercipta suatu situasi didaktis yang baru. Antisipasi guru tersebut menyangkut hubungan siswa dengan materi dan juga hubungan guru dengan materi baik secara individu, kelompok ataupun secara keseluruhan. Untuk itu, Suryadi [12] kemudian mengembangkan desain didaktis Kansanen dengan menambahkan Antisipasi Didaktis dan Pedagogis (ADP) sebagai suatu hubungan antisipasi guru dengan materi, hasilnya seperti pada Gambar 2.

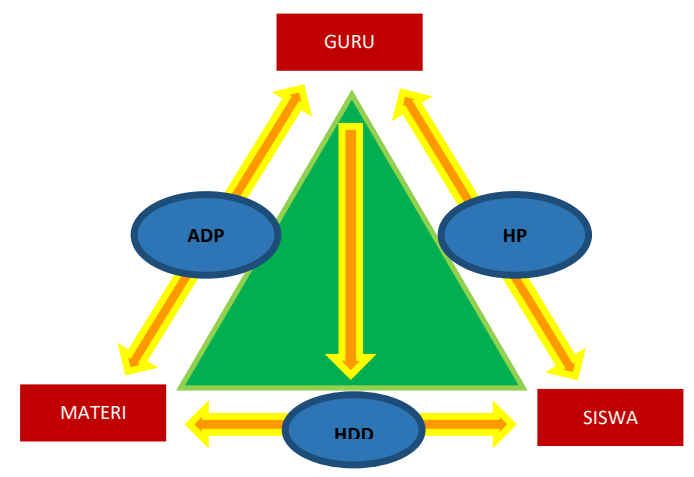

Sumber : Suryadi 2010

\section{Gambar 2. Segitiga Didaktis yang dimodifikasi}

Agar proses belajar dalam diri siswa (learning situation) muncul, maka peran guru dalam konteks segitiga didaktis adalah menciptakan situasi didaktis (didactical situation). Guru diharapkan mampu untuk menciptakan situasi didaktis agar proses belajar dapat berjalan dengan optimal, dimana guru perlu memiliki kemampuan untuk menciptakan relasi didaktis (didactical relation) antara siswa dengan materi agar tercipta situasi didaktis yang ideal. Dalam pembelajaran diharapkan terjadi interaksi pembelajaran antara guru, siswa, dan materi. Akan tetapi jika pada kondisi tertentu hubungan antara siswa dengan materi tidak terjalin, misalnya siswa tidak mampu menjelaskan keterkaitan antara objek dalam materi pembelajaran, guru dapat menggunakan teknik scaffolding untuk dapat menciptakan suatu proses belajar bagi siswa [12].

Jika dilihat lebih dalam situasi yang tercipta dalam pembelajaran sangatlah kompleks, untuk itu guru perlu memiliki kemampuan untuk memandang situasi didaktis dan pedagogis secara menyeluruh sehingga pembelajaran berjalan dengan optimal. Menurut Suyadi [12] kemampuan metapedadidaktik yaitu kemampuan guru untuk: (1) memandang komponen-komponen segitiga didaktis yang dimodifikasi yaitu ADP, HD, dan HP sebagai suatu kesatuan yang utuh, (2) mengembangkan tindakan sehingga tercipta situasi didaktis dan pedagogis sesuai kebutuhan siswa, (3) mengidentifikasi serta menganalisis respon siswa sebagai akibat tindakan didaktis maupun pedagogis yang dilakukan, (4) melakukan 
tindakan didaktis dan pedagogis lanjutan berdasarkan hasil analisis respon siswa menuju pencapaian target pembelajaran.

Penelitian ini berfokus pada analisis situasi didaktis melalui analisis learning obstacle yang dialami siswa dalam pembelajaran sifat-sifat bangun datar segiempat. Mengkaji materi dan soal-soal yang akan diberikan kepada siswa, mengaitkan suatu materi dengan materi sebelum atau sesudahnya. Dengan demikian guru dapat mengetahui hambatan apa yang mungkin akan dialami siswa, memprediksi respon yang akan diberikan siswa, dan dapat merancang serangkaian tindakan didaktis yang dapat dilakukan selama proses pembelajaran. Pengembangan desain didaktis memerlukan suatu proses berpikir yang mendalam dan menyeluruh tentang materi, respon siswa, dan antisipasi respon siswa. Proses berpikir guru dalam pengembangan desain didaktis dilakukan sebelum, saat, dan setelah pembelajaran. Proses sebelum pembelajaran dilakukan untuk menganalisis hambatan belajar (learning obstacle) siswa yang akan digunakan dalam penyusunan ADP yang merupakan sintesis hasil pemikiran guru dalam mengantisipasi segala peristiwa yang mungkin akan terjadi dalam pembelajaran.

Memahami teori tentang bagaimana orang belajar serta kemampuan menerapkannya dalam pembelajaran matematika merupakan persyaratan penting untuk menciptakan proses pembelajaran efektif [12]. Dalam pembelajaran terdapat beberapa teori pembelajaran yang disampaikan oleh ahli yang dijadikan landasan dalam pembelajaran matematika. Menurut teori Van Hiele, ketika mempelajari geometri, siswa mengalami perkembangan kemampuan berpikir dengan melalui 5 tahap yang bersifat hierarki yaitu: (1) Tahap Pengenalan (Visualisasi), pada ini siswa memandang suatu bangun geometri secara keseluruhan anak belum memperhatikan adanya sifat-sifat dari bangun geometri tersebut. Pada tahap ini siswa sudah mengenal nama suatu bangun, tetapi belum mengamati ciri dan sifat bangun tersebut; (2) Tahap Analisis, pada tahap analisis siswa sudah mulai mengenal bangun geometri berdasarkan ciri dari masingmasing bangun. Pada tahap ini siswa sudah bisa menyebutkan sifat-sifat dan mengamati unsur-unsur yang terdapat pada suatu bangun; (3) Tahap Pengurutan (Deduksi Informal), pada tahap pengurutan siswa mulai mampu melakukan penarikan kesimpulan, siswa sudah bisa memahami hubungan antara ciri yang satu dan ciri yang lain pada suatu bangun. (4) Tahap Deduksi, pada tahap deduksi siswa sudah mampu menarik kesimpulan secara deduktif, yaitu penarikan kesimpulan dari hal yang bersifat umum ke hal yang bersifat khusus. Dalam tahap ini anak sudah memahami makna dari suatu definisi, dalil, aksioma dan postulat; (5) Tahap Akurasi, pada tahap akurasi siswa sudah menyadari pentingnya prinsip dasar yang melandasi suatu pembuktian. Pada tahap ini, siswa memahami bahwa dimungkinkan adanya lebih dari satu geometri [13].

Menurut Van Hiele, setiap anak yang belajar geometri akan mengalami tahapan tersebut secara terurut tanpa ada tahapan yang diloncati. Akan tetapi, kapan seorang siswa mulai memasuki suatu tahap yang baru tidak selalu sama antara siswa yang satu dengan siswa yang lain. Selain itu, Van Hiele juga mengemukakan bahwa proses perkembangan dari tahap yang satu ke tahap berikutnya tidak ditentukan oleh umur atau kematangan biologis, tetapi lebih 
bergantung pada pengajaran dari guru dan proses belajar yang dilalui oleh siswa. Menurutnya tiga unsur utama dalam pembelajaran geometri adalah waktu, materi, dan metode pembelajaran yang diterapkan, jika ditata secara terpadu dapat meningkatkan kemampuan berpikir anak pada tingkat yang lebih tinggi.

Menurut Teori Piaget, tingkat perkembangan kognitif setiap individu menurut Piaget ada empat tahapan yaitu: (1) tahap sensorimotor (0-2 tahun), pada periode ini anak mengatur alamnya dengan indra (sensori) dan tindakannya (motor). Bagi anak, objek itu ada jika ada pada pengelihatannya. (2) tahap pra operasi (2-7 tahun), pada periode ini merupakan tahap persiapan operasi konkret berupa tindakan kognitif, seperti mengklasifikasikan objek, menata letak benda berdasarkan urutan, dan membilang. (3) tahap operasi konkret (7-11 tahun), anak pada tahap ini telah memahami operasi logis dengan bantuan benda-benda konkret anak sudah memahami konsep kekekalan, mengklasifikasikan dan mengurutkan, dapat memandang suatu objek dari sudut pandang yang berbeda, dan mampu berpikir reversibel. (4) tahap operasi formal (>11 tahun), pada tahap ini anak sudah mampu melakukan penalaran dengan menggunakan hal-hal abstrak dimana anak sudah tidak memerlukan benda konkret (Dahar, 2011).

Menurut Vygotsky dalam Suryadi [12], belajar dapat membangkitkan berbagai proses mental tersimpan yang hanya bisa dioperasikan saat seseorang berinteraksi dengan orang dewasa atau kolaborasi dengan sesama teman. Vygotsky juga mengenalkan teknik Scaffolding yaitu pemberian bantuan kepada anak pada masa awal perkembangannya, kemudian mengurangi bantuan tersebut dan memberikan tanggung jawab kepada anak untuk mengambil alih segera setelah anak dapat melakukannya sendiri. Menurut Vygotsky interaksi sosial itu penting saat siswa menginternalisasikan pemahaman, permasalahan dan proses yang sulit, dimana proses internalisasi melibatkan rekonstruksi aktivitas psikologis dengan dasar penggunaan bahasa untuk menegosiasi pengalamanpengalaman mereka [14].

\section{METODE}

Penelitian ini merupakan penelitian kualitatif dengan desain penelitian Didactical Design Research (DDR). Tujuan penelitian ini adalah menghasilkan desain didaktis sifat-sifat bangun datar segiempat yang dapat memfasilitasi siswa dalam belajar sehingga dapat meminimalisir hambatan belajar dalam diri siswa. Penelitian dilakukan pada tanggal 4-11 Mei 2020. Subjek penelitian ini adalah siswa kelas VII di satu SMP di Bandar Lampung. Dalam penelitian ini, Peneliti berperan sebagai alat pengumpul data utama dan didukung oleh instrumen lainnya seperti, lembar kerja siswa, pedoman wawancara, lembar observasi, foto, dan video rekaman saat pembelajaran. Hal tersebut sesuai dengan Moleong [15] yang menyatakan bahwa dalam penelitian kualitatif, peneliti merupakan alat pengumpul data utama, peneliti merupakan perencana, pelaksana pengumpulan data, analis, penafsir, dan pelapor hasil penelitian. Pengumpulan data dilakukan dengan menggunakan teknik triangulasi. "Triangulation is the process of corroborating evidence from different individuals, type of data, or method of data collection in description and themes in qualitative research" [16]. Analisis data dilakukan 
dengan menelaah seluruh data yang tersedia dari berbagai sumber, mulai dari sebelum, selama, dan setelah penelitian.

Prosedur penelitian ini terdiri dari tahap pendahuluan, implementasi desain didaktis, dan tahap akhir. Tahap pendahuluan terdiri dari: (1) memberikan tes learning obstacle yang terdiri dari 5 soal uraian tentang sifat-sifat bangun datar segiempat, (2) menganalisis learning obstacle yang dialami siswa berdasarkan jawaban siswa, studi literatur, dan observasi pembelajaran, (3) merancang desain didaktis hipotesis yang terdiri dari rancangan situasi didaktis, prediksi respon siswa yang mungkin muncul dan rancangan antisipasi didaktis sebagai upaya menangani kemungkinan respon siswa yang muncul berdasarkan prediksi respon. (4) mempersiapkan perangkat pembelajaran yang disesuaikan dengan desain didaktis yang telah dirancang. Tahap implementasi desain terdiri atas: (1) implementasi desain yang telah disusun, (2) merekam pembelajaran yang dilakukan. Pada tahap akhir dilakukan analisis proses dan hasil implementasi desain didaktis, serta analisis learning obstacle yang masih muncul berdasarkan hasil kerja siswa pada lembar kerja yang diberikan.

\title{
HASIL DAN PEMBAHASAN
}

\section{Learning Obstacle}

Hambatan belajar terlihat saat siswa menyebutkan bahwa suatu bangun dikatakan persegi jika alas persegi mendatar (horizontal), sedangkan jika suatu persegi alasnya tidak mendatar (horizontal) maka siswa berasumsi bahwa bangun tersebut bukan persegi. Pada soal tes learning obstacle nomor $4 \mathrm{~b}$, muncul hambatan dimana siswa tidak dapat mengaitkan sifat persegi dengan sifat belah ketupat.

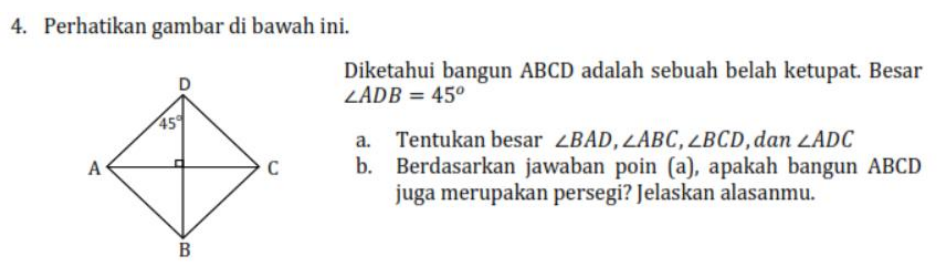

Gambar 3. Soal learning obstacle

\author{
Bukan,karena bangun datar tsb adalah belah \\ ketupat
}

\section{Gambar 4. Jawaban Siswa}

Didactical obstacle ditemukan pada beberapa materi yang diajarkan oleh guru yang berdampak pada pemahaman siswa terhadap sifat-sifat bangun datar segiempat. Berdasarkan analisis buku yang digunakan dalam pembelajaran, materi yang disediakan pada buku memfasilitasi siswa pada level kognitif pengetahuan, 
belum sampai pada level pemahaman sifat-sifat bangun datar segiempat. Gambar 5 menampilkan lembar kegiatan siswa yang digunakan dalam pembelajaran.

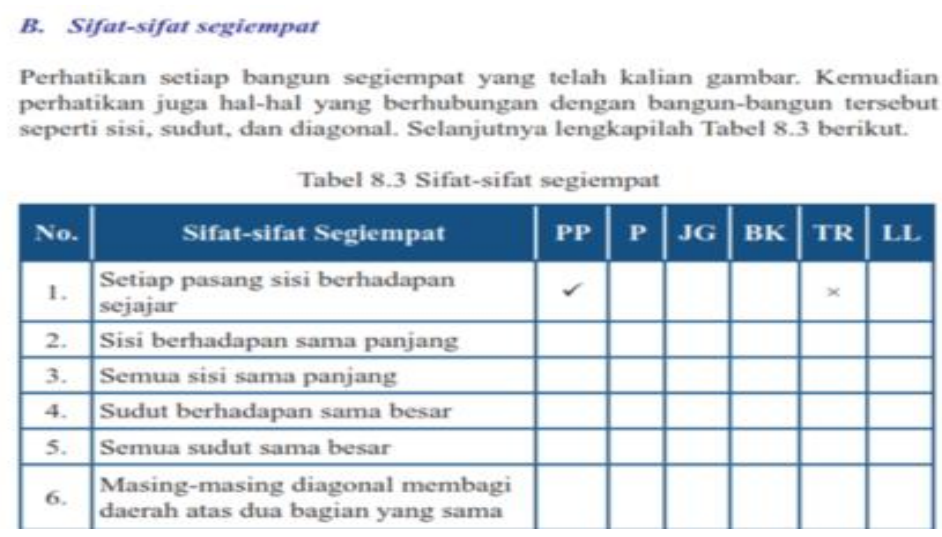

Gambar 5. Lembar Kegiatan pada Buku Siswa

Penyajian gambar pada materi belah ketupat memunculkan hambatan siswa berupa siswa terpaku pada bentuk belah ketupat dimana posisi salah satu sudutnya berada di bawah, seperti pada Gambar 6. Penyajian gambar tersebut dapat membuat siswa berpikir jika belah ketupat akan selalu seperti pada Gambar 6, sedangkan jika pada posisi lain maka bangun tersebut adalah persegi atau jajar genjang. Orientasi siswa terhadap suatu bangun datar masih berada pada visual atau tampilan gambar bukan pada sifat-sifat yang melekat pada bangun tersebut.

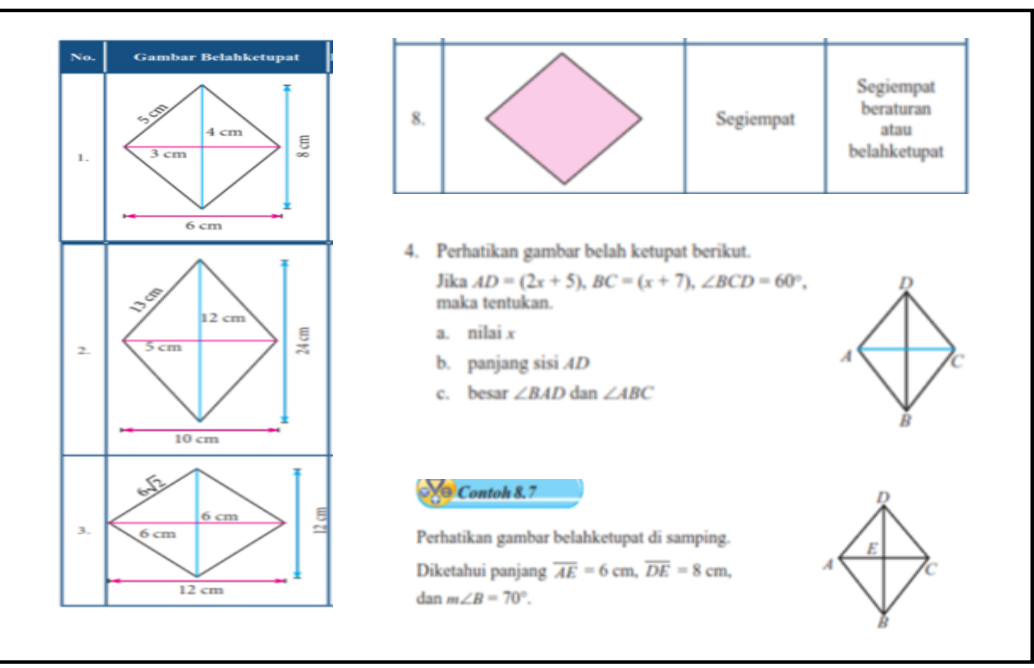

Gambar 6. Penyajian Gambar Belah Ketupat pada Buku Siswa 
Tabel 1. Hambatan Belajar Siswa

\begin{tabular}{ll|l}
\hline \multicolumn{1}{c}{$\begin{array}{c}\text { Tipe Hambatan } \\
\text { Belajar }\end{array}$} & \multicolumn{1}{c}{ Hambatan Belajar } \\
\hline Epistemologi & Tipe 1 & $\begin{array}{l}\text { Siswa hanya dapat membedakan bangun datar } \\
\text { berdasarkan gambar } \\
\text { Siswa tidak dapat mengaitkan sifat-sifat antar } \\
\text { Tipe 2 } \\
\text { bangun datar ketika orientasinya dirubah }\end{array}$ \\
\hline Didactical & Tipe 3 & $\begin{array}{l}\text { Pembelajaran yang dilakukan guru, pada level } \\
\text { pengetahuan } \\
\text { Penyajian gambar bangun datar kurang } \\
\text { bervariasi }\end{array}$ \\
\hline
\end{tabular}

\section{Desain Didaktis}

Berdasarkan learning obstacle yang teridentifikasi pada materi sifat-sifat bangun datar segiempat, serta analisis buku ajar yang digunakan oleh guru dan siswa, peneliti menyusun desain didaktis sesuai learning obstacle yang muncul. Desain didaktis disusun berdasarkan learning obstacle dan learning trajectory. Learning Obstacle diidentifikasi melalui tes learning obstacle sifat-sifat bangun datar segiempat yang diujikan pada siswa kelas VIII yang telah mempelajari materi tersebut. Learning trajectory merupakan lintasan belajar siswa sesuai tingkatan berpikir siswa berupa urutan materi saat pembelajaran. Learning trajectory disusun untuk membantu siswa agar dapat mengembangkan proses berpikirnya sehingga dapat mengatasi learning obstacle yang dialami.

Setelah menyusun learning trajectory, tahap selanjutnya adalah menyusun lesson design yang didalamnya mencakup situasi didaktis, prediksi respon, dan antisipasi didaktis. Penelitian ini terdiri dari tiga lesson design. Lesson design pertama disusun untuk membantu siswa memahami sifat-sifat bangun persegi dan persegi panjang. Lesson design kedua membahas sifat-sifat bangun jajargenjang dan belahketupat. Lesson design ketiga membahas sifat-sifat bangun trapesium dan layang-layang. Penyusunan lesson design diawali dengan mendesain situasi didaktis. Setelah situasi didaktis disusun, tahap berikutnya adalah membuat prediksi respon siswa. Prediksi respon siswa disusun berdasarkan hasil analisis learning obstacle awal. Prediksi respon siswa diuraikan untuk memprediksi semua kemungkinan respon atau jawaban siswa yang muncul. Prediksi respon ini digunakan sebagai acuan dalam perencanaan antisipasi didaktis. Antisipasi didaktis disusun agar pembelajaran dapat berjalan sesuai dengan yang diharapkan. Prediksi respon dan antisipasi didaktis membantu guru dalam mempersiapkan hal apa saja yang harus dilakukan ketika respon-respon tersebut benar-benar muncul saat implementasi desain. Dengan demikian dapat tercipta pembelajaran yang efektif. 


\section{Epistemologi Obstacle}

Materi bangun datar segiempat dipelajari siswa saat di sekolah dasar hingga sekolah menengah. Bisa dikatakan bahwa siswa sudah memiliki pengetahuan awal tentang bangun datar saat mempelajarinya di sekolah menengah. Pada tahap ini diharapkan siswa dapat menggunakan pengetahuan yang dimilikinya untuk lebih memahami sifat-sifat bangun datar segiempat. Berdasarkan hasil tes learning obstacle, ternyata muncul hambatan belajar dimana siswa tidak dapat menggunakan pengetahuan yang dimiliki ketika dihadapkan pada permasalahan yang diberikan. Hal ini terlihat saat siswa mengalami kesulitan saat mengaitkan sifat bangun persegi dan bangun belah ketupat.

Menurut teori Van Hiele siswa pada sekolah menengah umumnya berada pada tahap deduksi formal, yang menandakan bahwa tingkat berpikir siswa sudah mencapai tahap visualisasi dan tahap analisis. Hasil analisis jawaban siswa tentang sifat-sifat bangun datar menunjukkan bahwa, siswa hanya menggunakan kemampuan visualisasi mereka tanpa mengaitkannya dengan informasi yang mereka miliki. Siswa menyatakan suatu bangun dikatakan persegi jika posisi alasnya mendatar (horizontal), sedangkan jika tidak mendatar mereka berasumsi bahwa bangun tersebut bukan persegi

Setelah menganalisis buku yang digunakan siswa saat pembelajaran, terlihat bahwa penyajian gambar bangun persegi, alasnya selalu mendatar. Sedangkan untuk belah ketupat, posisi salah satu sudutnya selalu berada di bawah. Penyajian gambar bangun seperti ini menggiring siswa untuk berasumsi bahwa persegi alasnya selalu mendatar, jika tidak maka bukan persegi. Hal ini dapat mempengaruhi pemahaman siswa terhadap sifat suatu bangun. Untuk mengatasi obstacle tersebut desain didaktis yang disusun menyajikan berbagai macam bentuk bangun datar segiempat dalam segala posisi baik alasnya mendatar ataupun tidak. Hal ini dilakukan dengan harapan pemahaman siswa tentang sifatsifat bangun datar segiempat dapat berkembang lebih luas dan siswa dapat mengaitkan sifat antar bangun dengan tepat.

\section{Didactical Obstacle}

Pembelajaran sifat-sifat bangun datar segiempat yang dilakukan guru dikelas, materi disajikan dengan menggunakan tabel ceklis sifat-sifat bangun datar segiempat seperti pada Gambar 5. Penggunaan tabel ceklis tersebut memudahkan guru dalam penyampaian materi, siswa dapat mengetahui unsur-unsur yang terdapat pada suatu bangun datar sesuai pernyataan yang disediakan. Pernyataan yang disediakan bersifat tertutup dan siswa diminta memilih unsur yang sesuai dengan bangun tertentu. Hal tersebut dapat mengasah level pengetahuan siswa tentang unsur suatu bangun, akan tetapi untuk kemampuan pemahaman siswa dalam mengaitkan sifat-sifat bangun datar, cara tersebut dirasa kurang efektif. Hal tersebut dapat membatasi proses berpikir siswa dalam hal mengaitkan informasi 
yang mereka miliki dengan informasi baru yang mereka peroleh terutama pada materi sifat bangun datar.

Berdasarkan analisis buku yang digunakan siswa, juga ditemukan hambatan Tipe 3 yang menunjukkan bawa kemampuan siswa dalam mengaitkan informasi yang diperoleh dengan pengetahuan awal mereka terbatas. Untuk mengatasi hambatan Tipe 3 ini, dalam setiap situasi didaktis, peneliti memberikan permasalahan kontekstual disertasi scaffolding berupa pertanyaan terbuka. Tujuan dari pemberian pertanyaan terbuka adalah agar siswa dapat mengeksplorasi informasi secara lebih luas, dan diharapkan siswa akan terbiasa memikirkan berbagai kemungkinan.

Dalam mengaitkan sifat-sifat persegi dan belah ketupat, siswa fokus pada gambar yang disediakan. Orientasi siswa terhadap suatu bangun datar masih berada pada visual atau tampilan gambar bukan pada sifat-sifat yang melekat pada bangun tersebut. Menurut siswa bentuk bangun belah ketupat adalah seperti pada Gambar 6, sedangkan bangun persegi, salah satu sisinya horizontal seperti pada Gambar 9.

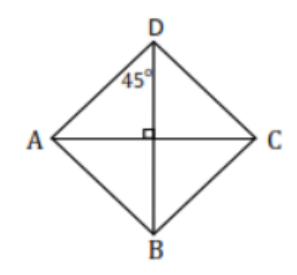

\section{Gambar 7. Belah Ketupat}

Dari gambar di atas, siswa diminta menjelaskan apakah bengun belah ketupat tersebut bisa dikatakan sebagai bangun persegi. Kegiatan ini diberikan untuk mengetahui apakah siswa mampu mengaitkan sifat-sifat bangun belah ketupat dan persegi. Jika siswa mampu mengaitkan sifat-sifat bangun datar dengan tepat, siswa tidak akan kesulitan dalam menyelesaikan masalah yang membutuhkan pemahaman tersebut. Akan tetapi jika siswa belum mampu mengaitkan sifat-sifat antar bangun datar, memungkinkan siswa akan mengalami kesulitan dalam menyelesaikan permasalahan. Berikut adalah salah satu contoh jawaban siswa pada tes learning obstacle awal.

Karena semua sudutnya $90^{\circ}$ bisa dibilang belah ketupat ini saat dimiringkan $45^{\circ}$ bisa jadi persegi empat.

\section{Gambar 8. Jawaban Siswa}


Dari jawaban siswa tersebut, diduga bahwa siswa terbiasa disajikan gambar bangun persegi dengan alas persegi selalu mendatar (horizontal). Penyajian gambar persegi yang sisi alasnya selalu mendatar membuat siswa berasumsi jika alasnya tidak mendatar maka bangun tersebut bukan persegi. Hal ini juga terjadi pada bangun datar belah ketupat, jika gambar yang disajikan berbeda dari yang biasa mereka lihat, maka mereka berasumsi bangun tersebut bukan bangun belah ketupat walaupun sifat-sifat bangun belah ketupat sudah terpenuhi. Siswa akan mengalami kesulitan dalam mengaitkan informasi yang dimilikinya ketika orientasi gambar diubah. Hal ini membatasi konteks siswa dalam memahami keterkaitan sifat-sifat bangun persegi dan belah ketupat. Berdasarkan analisis buku pelajaran matematika yang digunakan siswa, terlihat penyajian gambar bangun persegi seperti pada Gambar 9 dan belahketupat seperti pada Gambar 6.

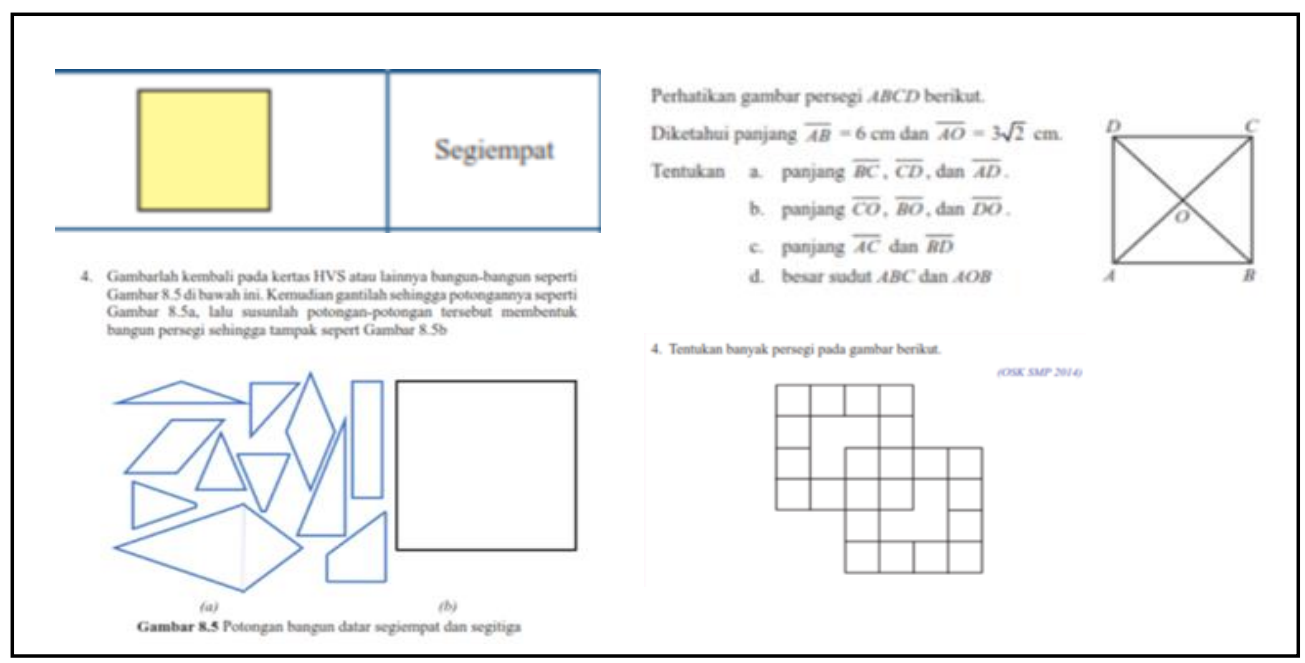

Gambar 9. Penyajian gambar persegi pada buku siswa

Berdasarkan beberapa gambar di atas, terlihat bahwa gambar persegi selalu disajikan dengan alas mendatar (horizontal), sedangkan penyajian gambar belahketupat selalu salah satu sudutnya berada di bagian bawah. Hal ini dapat mengakibatkan konteks siswa tentang bangun persegi dan belahketupat terbatas pada orientasi bangun yang selalu ditampilkan seperti pada gambar. Jika tidak sesuai dengan gambar yang biasa mereka lihat, maka bangun tersebut bukan termasuk bangun yang sedang mereka pelajari. Tentunya hal ini akan menghambat proses pemahaman siswa tentang keterkaitan bangun datar yang satu dengan yang lain.

Berdasarkan segitiga didaktis, peran guru dalam proses pembelajaran adalah menciptakan situasi didaktis antara siswa dan materi pelajaran. Keterkaitan antara guru, siswa dan materi pelajaran sangatlah erat dan kompleks. Seperti halnya learning obstacle yang muncul pada materi sifat-sifat bangun datar segiempat, yaitu ontogenic obstacle, epistemologi obstacle, dan didactical obstacle. Masing-masing obstacle muncul dari dalam diri siswa, proses 
pembelajaran yang dilakukan guru, dan dari materi pembelajaran. Jika salah satu learning obstacle muncul, maka dapat mengakibatkan atau mempengaruhi kemunculan learning obstacle lainnya.

Untuk mengatasi hambatan Tipe 4, maka peneliti merancang situasi didaktis yang didalamnya menampilkan bangun datar dalam beberapa orientasi. Sebagai contoh pada situasi didaktis menemukan sifat-sifat bangun belah ketupat, peneliti meminta siswa untuk menggambarkan beberapa bangun belah ketupat yang berbeda. Hal ini dilakukan agar siswa terbiasa berpikir bahwa bangun belah ketupat tidak hanya seperti Gambar 6. Jadi meskipun orientasinya diubah bangun tersebut tetaplah bangun belah ketupat dan sifat-sifat yang dimilikinya juga tidak berubah. Setelah siswa menemukan berbagai bentuk bangun belah ketupat dan mengidentifikasi sifat-sifatnya, peneliti mengarahkan siswa untuk mengaitkan sifat-sifat bangun belah ketupat dan persegi. Demikian juga dalam merancang situasi didaktis bangun datar lainnya yang saling berkaitan, peneliti juga mengarahkan siswa untuk mengidentifikasi keterkaitan sifat-sifat antar bangun datar lainnya.

\section{KESIMPULAN}

Learning obstacle yang teridentifikasi pada penelitian desain didaktis sifat-sifat bangun datar segiempat yaitu didactical obstacle, dan epistemological obstacle. Kedua jenis learning obstacle ditemukan melalui analisis jawaban siswa kelas VII SMP pada tes instrumen learning obstacle materi sifat-sifat bangun datar dan analisis buku teks matematika. Desain yang dikembangkan berdasarkan hasil analisis pendahuluan serta disesuaikan dengan learning trajectory untuk meminimalkan hambatan yang dialami siswa dalam memahami materi sifat-sifat bangun datar segiempat. Desain didaktis empirik materi sifatsifat bangun datar segiempat dikembangkan berdasarkan hasil analisis implementasi desain.

\section{DAFTAR RUJUKAN}

[1] Bobango. (1993). Geometri for All Students: Phase-Based Instructions. Dalam cuevas (ads). Reaching all students with mathematics. Virginia: the National Council of Teacher of Mathematics Brosusseau, G. (2002). Theory of Didactical Situation in Mathematics. Dordrecht: Kluwer Academic Publisher

[2] Hardianti D., Priatna N., \& Priatna B. A. (2017). Analysis of Geometric Thinking Students' and Process-Guided Inquiry Learning Model. Journal of Physics: Conf. Series 895 (2017) 012088.

[3] National Council of Teachers of Mathematics. (2000). Principles and Standards for School Mathematics. Reston, VA: NCTM

[4] Ozerem, A. (2012). Misconception in geometry and suggested solutions for seventh grade students. International Journal of New Trends in Arts, Sports \& Science Education-2012, volume 1, issue 4.

[5] Biber C., Tuna A., \& Korkmaz S.(2013). The mistakes and the misconceptions of the eighth grade students on the subject of angels. European Journal of Science and Mathematics Education vol. 1 No. 2 50-59. 
[6] Sunardi. (2012) Analisis kemampuan berpikir geometri siswa berdasarkan teori Van Hiele. Jurnal Inkuiri Vol. 1 No. 2

[7] Brosseau, G. (2002). Theory of didactical situation in mathematics. New York: Kluwer Academic Publishers.

[8] Brown, S. A. \& College, P. (2008). Exploring Epistimologycal Obstacle to The Development of Mathematics Induction. Procceding of 11th Conference for Reasearch on Undergraduate Mathematics Education. Hlm. 1-9

[9] Nyiikahadzoyi, M.R., Mapuwei, T., \& Chinyoka, M. (2013). Some Cognitive Obstacles Faced By 'A' Level Mathematics Students in Understanding Inequalities: A Case Study of Bindura Urban High Schools. International Journal of Academic Research in Progressive Education and Development. Vol. 2, No. 2 ISSN: 2226-6348. Hlm 206-221

[10]Suryadi, Didi. (2010). Didactical Design Research (DDR) Dalam Pengembangan Pembelajaran Matematika. Makalah pada Seminar Nasional Pembelajaran MIPA UM Malang 13 November 2010

[11] Kansanen, Pertti. (2003). Studying the Realistic Bridge Between Instruction and Learning. An Attempt to a Conceptual Whole of the Teaching-StudyingLearning Process. Educational Studies, Vol.29, No.2/3, 221-232

[12] Suryadi, Didi. (2010). Menciptakan Proses Belajar Aktif: Kajian dari Sudut Pandang Teori Belajar dan Teori Didaktik. Makalah pada Seminar Nasional Pendidikan Matematika di UNP, 9 Oktober 2010

[13] Vah Hiele. (1999). Developing Geometric Thinking Trought Activities that Begin with Play. Reston VA: NCTM.

[14]Dahar, Ratna Wilis. (2011). Teori-teori Belajar dan Pembelajaran. Bandung: Erlangga

[15] Moelong, Lexy J. (2015). Metodologi Penelitian Kualitatif . [edisi revisi]. Bandung: PT Remaja Rosdakarya

[16]Creswell, John W. (2012). Educational Research: planning, conducting and evaluating quantitative and qualitative research. Boston: Pearson Education 